\title{
НОВЫЕ ДАННЫЕ О ГЕОЛОГИЧЕСКОМ СТРОЕНИИ НЕОКОМСКОГО НЕФТЕГАЗОПЕРСПЕКТИВНОГО КОМПЛЕКСА ЗАПАДНОЙ ЧАСТИ НАДЫМ-ТАЗОВСКОЙ СИНЕКЛИЗЫ
}

Самсонова Н.A., Насонов В.A. (ЗАО "НПЦ"СибГео")

В работе приведены новые сведения о геологическом строении и перспективах нефтегазоносности отложений неокома на Аномальной площади, расположенной в западной части Надым-Тазовской геосинеклизы, полученные по результатам сейсморазведочных и буровых работ 2005-2006 гr.

В докладе дано краткое описание истории развития геологоразведочньгх работ в районе исследований, его геологическое строение с огисанием литолого-стратиграфической характеристикой разреза, тектоники и нефтегазоносного районирования.

Для создания априорной геологической модели строения района работ были проинтерпретированы 23 глубоких скважины. Построены корреляционные схемы через Ярудейскую- Кушелевскую - Западно-Медвежьюю площади. Для шельфовых пластов по результатам интерпретации построены карты развития коллекторов. Покоррелированы опорные и реперные отражающие горизонты. В интервале шельфовых пластов в ундаформной зоне выделены субфачия. Выполнено ПАК преобразование временных сейсмических разрезов. Выполнены структурные построения по всем закартированным отражениям. Проанализированы основные закономерности распределения мощностей сейсмостратиграфических комплексов, выполнено восстановление палеотектонической обстановки и определены источники сноса в отдельные геологические периоды.В интервале неокома выделены нефтегазоперспективные объекты структурного и структурно-литологического типа. Произведена оценка подтотовленных и выделенных объектов.

Выполнена корреляция основныт продуктивных пластов по данньм бурения в районе Аномального участка. По всем пробуренным скважинам в интервале шельфовых пластов было проведено литологическое расчленение разреза и оценка характера насыщения, определены стратиграфическая мощность, эффективная мощность, выделены участки с улучшенными коллекторскими свойствами. Схемы корреляции тельфовых пластов сделаны по скважинам с учетом корреляции отражающих горизонтов на композитных сейсмических временных разрезах. Это заставило пересмотреть и изменить индексацию по нижним шельфовым пластам на скважинах, пробуренных к западу от площади работ с учетом их "сваливания" в фондоформную глубоководную зону, находившуюся во время формирования этих пластов в пределах площади проведенных работ, пто послужило основанием для рассматривания перспектив нефтегазоносности картируемых нижних шельфовых пластов, как генетических аналогов, соотносимых с восточными площадями.

Построены карты эффективных мошностей, иллюстрируюшие развитие коллекторов в шельфо-

вых пластах $\mathrm{AH}_{11}, \mathrm{bH}_{0}, \mathrm{bH}_{1}, \mathrm{bH}_{2-3}, \mathrm{bH}_{4}, \mathrm{bH}_{7}, \mathrm{bH}_{8}$, $\mathrm{bH}_{9}, \mathrm{5H}_{10}{ }^{0}$ в пределах Аномального участка по данным бурения. Результаты анализа этих карт свидетельствуют о существенном развитии на разных стратиграфических уровнях неокома в пределах площади исследований песчаных пластов с различной эффективной мощностью. Установлено, что наибольшее площадное распространение на площади исследований получили верхние шельфовые пласты $\mathrm{AH}_{11}, \mathrm{БH}_{0}, \mathrm{БH}_{1}, \mathrm{БH}_{2-3}, \mathrm{БH}_{4}$. Выявлен характер распределения суммарной толшины коллектора шельфовых пластов Аномального участка и прилегающих площадей.

На примере пласта $\mathrm{bH}_{2-3}$ описана методика ПАК-преобразования разрезов в качестве дополнительного сейсмитеского атрибута..

В результате инверсия получены разрезы акустического импеданса с низкочастотной составляющей скоростей и нормализованные разрезы акустического импеданса без низкочастотной составляющей. Сопоставление результатов инверсия с исходным ПАМ-разрезом по пр.3585032 свидетельствует в пользу разрезов акустического импеданса, т.к. на разрезах импеданса изображаются пласты и интервалы геологического разреза с определенными близкими физическими свойствами, в то время как на временных разрезах представлено волновое поле как суперпозищия отдельньх отражений. Кроме того, на разрезах импеданса с низкочастотной составляющей скорости представлены абсолютные значения скоростей, а это важно для моделирования волновьгх полей и геологического анализа. Несмотря на присутствие в примененной процедуре значительной доли условности, разрезы псевдоимпедансов по профилям, пересекающим самые значительные Аномальное и Ачаяхское поднятия помогли получить в неразбуренной части площади дополнительную информацию о литологии разреза, недоступную в случае применения других методов прогнозирования. Врезультате проведенных на Аномальном участке работ выполнены корреляция и картопостороение по ОГ неокомского НГПК, уточнено морфологическое строение основных шельфовых горизонтов, подтверждено существование ряда локальных поднятий. Авторы доклада выражают благодарность руководству ООО "Тайликснефтегаз" за разрешение использовать сейсмические и геологические материалы по Аномальной площади.

\section{ЛИТЕРАТУРА}

1. Бородкия В.Н., Брехунцов А.М., Дещеня Н.П. Особенности строения, корреляции и индексации основньх продуктивных резервуаров (птастов) неокома севера Западной Сибири в связи с условиями их осадконакопления. Геология, геофизика и разработка нефтяных месторожденкй, Москва, ВНИИОЭНГ, №2, 2000 . c. 7-17.

2. Насонов В.А., Самсонова Н.А. Отчет о результатах комплексной интерпретации по материалам сейсморазведки и бурения по Аномальной плошади. ЗАО НПЦ СибГЕО за 2007 r. 